\title{
Rapid Carbapenemase Detection With Xpert Carba-R V2 Directly On Positive Blood Vials
}

This article was published in the following Dove Press journal:

Infection and Drug Resistance

\author{
Aurélie Cointe ${ }^{1,2}$ \\ Violaine Walewski ${ }^{1,3}$ \\ Claire Amaris Hobson (iD) \\ Catherine Doit ${ }^{1,2}$ \\ Philippe Bidet ${ }^{1,2}$ \\ Laurent Dortet (iD ${ }^{4-6}$ \\ Stéphane Bonacorsi ${ }^{1,2}$ \\ André Birgy ${ }^{1,2}$ \\ 'IAME, UMR II37, INSERM, Université \\ Paris Diderot, Sorbonne Paris Cité, AP- \\ HP, Service de Microbiologie, Hôpital \\ Robert-Debré, AP-HP, Paris, France; \\ ${ }^{2}$ Service de Microbiologie, Centre \\ National de Référence associé \\ Escherichia coli, Hôpital Robert-Debré, \\ AP-HP, Paris, France; ${ }^{3}$ Service de \\ Microbiologie, Hôpitaux Universitaires \\ de Paris Seine Denis (HUPSSD), site \\ Avicenne, AP-HP, Bobigny, France; \\ ${ }^{4}$ EA736I, Université Paris-Sud, Université \\ Paris-Saclay, LabEx Lermit, Service de \\ Bactériologie-Hygiène, Hôpital Bicêtre, \\ AP-HP, Le Kremlin-Bicêtre, France; \\ ${ }^{5}$ Centre National de Référence associé \\ de la résistance aux antibiotiques: \\ Entérobactéries productrices de \\ carbapénémases, Le Kremlin-Bicêtre, \\ France; ${ }^{6}$ Evolution et Ecologie de la \\ résistance aux antibiotiques, Institut \\ Pasteur - APHP -Université Paris Sud, \\ Paris, France
}

\begin{abstract}
The rapid detection of carbapenemase allows implementation of infection control measures and adaptation of antibiotic therapy. We evaluated the performances of the Xpert Carba-R V2 ${ }^{\circledR}$ assay for the direct detection and identification of carbapenemase on positive blood cultures. We focused our evaluation on its detection capacity and on the risks of interference due to the patient's blood. Isolates of several variants of OXA-48-like $(n=10)$, KPC $(n=10), \operatorname{NDM}(n=11)$, VIM $(n=7)$, IMP-1 $(n=1)$ carbapenemases and 14 non carbapenemase-producing Enterobacteriaceae were tested. For each isolate $(\mathrm{n}=53)$, an aerobic vial was seeded, and incubated in Bactec Fx (Becton Dickinson ${ }^{\circledR}$ ) automate. When positive, the $\mathrm{Xpert}^{\circledR}$ Carba-R-V2 assay was assessed for carbapenemase detection using $40 \mu 1$ aliquot. Reproducibility tests were performed on a subset of 23 isolates using aerobic and anaerobic vials. Longer incubation time was also evaluated on 6 isolates. A complementary prospective study in real-time testing of patient-derived clinical samples on 20 additional positive blood vials with Gram negative bacilli on direct examination was performed. Perfect sensitivity and specificity $(100 \%)$ were observed regardless of the carbapenemase type, the blood vials used and the time of incubation. Xpert ${ }^{\circledR}$ Carba-R-V2 assay is suitable for the rapid detection of the main carbapenemase genes directly on positive blood vials. Its performances and rapid time analysis allow its use in routine to guide therapeutic choices and to implement infection control measures.
\end{abstract}

Keywords: carbapenemase, rapid detection, positive blood culture, GeneXpert, antibiotic therapy, infection control measures

\section{Introduction}

The rapid dissemination of carbapenemase-producing (CP) Enterobacteriaceae (CPE) throughout the world is worrisome and threatens public health. Early detection of patients carrying and/or infected by a CP isolate is a real challenge to implement infection control measures, which limit the risk of hospital spread, and to adapt the antibiotic therapy in case of infection, as it has been shown to improve the patients' survival. ${ }^{1}$

The prevalence and distribution of CP types and variants vary geographically. ${ }^{2}$ These enzymes are organized in 3 classes according to the Ambler classification: class B metallo- $\beta$-lactamases; including IMP, VIM, and NDM; class A $\beta$-lactamases such as Klebsiella pneumoniae carbapenemase (KPC) and the class D $\beta$-lactamase OXA-48 and variants.

A variety of tests are commercialized to detect carbapenemase activity or the genes encoding these proteins (colorimetric-based assays, ${ }^{3}$ phenotype-based assays, ${ }^{4,5}$ Matrix Assisted Laser Desorption Ionisation - Time of Flight (MALDI-TOF)
Correspondence: André Birgy Service de Microbiologie, Hôpital Robert Debré, 48 Boulevard Serrurier Paris F75019, France

Tel $+33 \mid 40034060$

Fax +33|40032450

Email andre.birgy@aphp.fr 
carbapenem hydrolysis assays, ${ }^{6}$ immunochromatographic assays $^{7}$ and PCR-based method ${ }^{8,9}$ but only a few of them have been evaluated directly on biological samples.

Fully automated PCR-based tests, which provide result in less than an hour, have been developed in recent years making this method attractive. Among these, the $\mathrm{Xpert}{ }^{\circledR}$ Carba-R V2 (Cepheid, Sunnyvale, CA 94.089 United States) is a real-time PCR assay for rapid detection and differentiation of 5 genes (bla $a_{\mathrm{KPC}}, b l a_{\mathrm{VIM}}, b l a_{\mathrm{IMP}-1}$, $b l a_{\mathrm{NDM}}$ and $b l a_{\mathrm{OXA}-48}$ and variants) responsible for carbapenem resistance in Enterobacteriaceae. It is "European Conformity In Vitro Diagnostics (CE IVD)" marked to detect fecal colonization for surveillance and screening purposes, with excellent sensitivity and specificity, ${ }^{8}$ and it is also validated for polymicrobial specimens such as abdominal drainage fluid and bronchial specimens. ${ }^{10,11}$

In this work, we evaluated the performances of the Xpert $^{\circledR}$ Carba-R V2 (Cepheid, Sunnyvale, CA 94.089 United States) assay for the detection of CPE directly on positive blood cultures. We focused our evaluation on its detection capacity and on the risks of interference due to the patient's blood by testing several vials for the same isolate.

\section{Materials And Methods}

\section{Isolates}

We tested previously characterized variants of OXA-48like $(n=10)$, KPC- $(n=10)$, NDM- $(n=11), \operatorname{IMP-1}(n=1)$ and VIM-type $(n=7) \mathrm{CPE}^{5,7}$ and 14 non-CPE (Table 1$)$.

\section{Blood Vials And Sample Preparation}

Isolates were cultured from frozen stock on TrypticaseSoy agar (Biomérieux, Marcy l'Etoile, France) at $35^{\circ} \mathrm{C}$ for 18h. First, from an isolated colony, a suspension of $10^{4}$ $\mathrm{CFU} / \mathrm{mL}$ was prepared in sterile water. For each isolate $(\mathrm{n}=53)$, we inoculated $1 \mathrm{~mL}$ of this suspension in an Aerobic/F vial (Becton Dickinson, Franklin Lakes, New Jersey, United States) containing human blood, which was then incubated in the BactecFx until positive. To approach the clinical conditions, we used the vials that remained negative after 5 days of incubation, which we anonymized. Our study was conducted in a Paediatric Hospital hence the volumes of blood in the samples were variable. To evaluate the impact of blood composition, each vial selected corresponded to a different patient.

Second, at positivity, a $40 \mu \mathrm{l}$ aliquot (or $400 \mu \mathrm{l}$ aliquot during the development step) was directly mixed with
Sample Reagent Buffer and the cartridge was launched with $1.7 \mathrm{~mL}$ of this mix.

Third, to test the reproducibility of the test on different blood samples, we seeded and evaluated for carbapenemase detection 2 further vials (1 Plus Aerobic/F and 1 Lytic/10Anaerobic/F) per selected isolate (CPE OXA-48like $(n=5), \operatorname{KPC}(n=5), \operatorname{NDM}(n=5)$, IMP $(n=1)$, VIM $(\mathrm{n}=5)$ and 2 non-CPE), corresponding to 46 supplementary vials. Then, as in some healthcare centers, positive blood vials during the night are only tested the next morning, we selected 1 isolate per carbapenemase type and 1 non-CP isolate for which the 3 vials ( 2 aerobic and 1 anaerobic) were re-incubated after positivity for $24 \mathrm{~h}$ at $35^{\circ} \mathrm{C}$ before repeating the test (18 vials in total). Finally, in order to approach the clinical conditions, a complementary prospective study in real-time testing of patient-derived clinical samples on 20 additional positive blood vials with Gram negative bacilli on direct examination was performed.

We analyzed the inoculum by plating bacterial dilutions onto TSA and quantified the colonies after $18 \mathrm{~h}$ of incubation. For all the samples, a minimum of $10^{7} \mathrm{CFU} /$ $\mathrm{mL}$ was observed.

\section{Results}

A total of 137 blood vials were tested in different conditions including 73 Aerobic vials as soon as they were positive (corresponding to 53 different isolates and the 20 vials for the prospective study), 23 Aerobic and 23 Anaerobic vials to test the reproducibility of the test with different patients' blood and 18 (12 Aerobic and 6 Anaerobic) to repeat the test after $24 \mathrm{~h}$ of further incubation. We also evaluated the impact of the aliquot volume, and for that, we experienced using $400 \mu \mathrm{l}$ aliquot and a hemolysis step. In this latter experience, the detection of carbapenemase genes with the Xpert ${ }^{\circledR}$ Carba-R V2 assay (Cepheid, Sunnyvale, CA 94089 United States) was correct for $21 / 24$ tested positive blood vials $(87.5 \%)$. The 3 remaining $(15 \%)$ led to errors in the reaction on the GeneXpert device (error 2008 related to syringe pressure due to hyperviscous samples). Further tests (results not shown) showed that hemolysis was not mandatory with $40 \mu 1$ samples.

Whatever the tested conditions, no further error occurred when using the $40 \mu \mathrm{l}$ aliquot, and all the positive blood vials seeded with CP isolates were correctly characterized either at time of positivity or after $24 \mathrm{~h}$ of further incubation. The 14 non-CP isolates were tested negative. 
Table I Results Of The Xpert Carba-R V2 ${ }^{\circledR}$ Assay Performed On Positive Blood Cultures Seeded With Carbapenemase-Producing Enterobacteriaceae

\begin{tabular}{|c|c|c|c|c|c|c|c|}
\hline $\begin{array}{l}\text { Carbapenemase } \\
\text { Type }\end{array}$ & Isolates & $\begin{array}{l}\text { Carbapenemase } \\
\text { Gene }\end{array}$ & $\begin{array}{l}\text { Other Betalactamases } \\
\text { Genes }\end{array}$ & $\begin{array}{l}\text { Total } \\
\text { Number Of } \\
\text { Tested Vials }\end{array}$ & $\begin{array}{l}\text { Positive } \\
\text { Xpert }^{\circledR} \text { Carba- } \\
\text { R Assay }\end{array}$ & $\begin{array}{l}\text { Sensitivity } \\
\text { (\%) }\end{array}$ & $\begin{array}{l}\text { Specificity } \\
\text { (\%) }\end{array}$ \\
\hline \multirow{10}{*}{$\begin{array}{l}\text { OXA-48 and } \\
\text { variants }(n=10)\end{array}$} & \multirow[t]{2}{*}{ E. coli } & OXA-48 & - & \multirow[t]{10}{*}{23} & \multirow[t]{10}{*}{23} & \multirow[t]{10}{*}{100} & \multirow[t]{10}{*}{100} \\
\hline & & OXA-I8I & CTX-M-I5, TEM-I, OXA-I & & & & \\
\hline & \multirow[t]{3}{*}{ K. pneumoniae } & OXA-48 & CTX-M-I5, TEM-I, OXA-I & & & & \\
\hline & & OXA-48 & $\begin{array}{l}\text { CTX-M group I, TEM-I, } \\
\text { OXA-I }\end{array}$ & & & & \\
\hline & & OXA-244 & CTX-M group 9, TEM-I & & & & \\
\hline & \multirow[t]{2}{*}{ K. oxytoca } & OXA-|8I & - & & & & \\
\hline & & OXA-48 & - & & & & \\
\hline & C. koseri & OXA-|8I & - & & & & \\
\hline & C. freundii & OXA-48 & - & & & & \\
\hline & E. cloacae & OXA-48 & - & & & & \\
\hline \multirow[t]{10}{*}{ KPC $(n=10)$} & \multirow[t]{2}{*}{ E. cloacae } & KPC-2 & TEM, OXA-9 & \multirow[t]{10}{*}{23} & \multirow[t]{10}{*}{23} & \multirow[t]{10}{*}{100} & \multirow[t]{10}{*}{100} \\
\hline & & KPC-3 & TEM-I, OXA-I & & & & \\
\hline & E. aerogenes & KPC-2 & TEM-I, SHV-2 & & & & \\
\hline & E. coli & KPC-2 & CTX-M group I, TEM & & & & \\
\hline & \multirow[t]{6}{*}{ K. pneumoniae } & KPC-2 & TEM & & & & \\
\hline & & $\mathrm{KPC} *$ & - & & & & \\
\hline & & KPC-2 & TEM-I & & & & \\
\hline & & KPC-2 & CTX-M group I, TEM & & & & \\
\hline & & KPC* & CTX-M group I, TEM & & & & \\
\hline & & KPC* & TEM & & & & \\
\hline \multirow[t]{11}{*}{ NDM $(n=11)$} & \multirow[t]{4}{*}{ E. coli } & NDM-I & CTX-M-I5, TEM-I & \multirow[t]{11}{*}{24} & \multirow[t]{11}{*}{24} & \multirow[t]{11}{*}{100} & \multirow[t]{11}{*}{100} \\
\hline & & NDM-5 & TEM-I, OXA-I & & & & \\
\hline & & NDM* & TEM, SHV, OXA-I & & & & \\
\hline & & NDM* & OXA-I & & & & \\
\hline & P. mirabilis & NDM-I & CTX-M group I & & & & \\
\hline & C. freundii & NDM-I & TEM, SHV, OXA-I & & & & \\
\hline & C. farmeri & NDM-I & CTX-M group I & & & & \\
\hline & E. cloacae & NDM* & - & & & & \\
\hline & \multirow[t]{3}{*}{ K. pneumoniae } & NDM-I & CTX-M-I5, TEM-I, OXA-I & & & & \\
\hline & & NDM-5 & CTX-M group I & & & & \\
\hline & & NDM-I & CTX-M group I & & & & \\
\hline
\end{tabular}


Table I (Continued).

\begin{tabular}{|c|c|c|c|c|c|c|c|}
\hline $\begin{array}{l}\text { Carbapenemase } \\
\text { Type }\end{array}$ & Isolates & $\begin{array}{l}\text { Carbapenemase } \\
\text { Gene }\end{array}$ & $\begin{array}{l}\text { Other Betalactamases } \\
\text { Genes }\end{array}$ & $\begin{array}{l}\text { Total } \\
\text { Number Of } \\
\text { Tested Vials }\end{array}$ & $\begin{array}{l}\text { Positive } \\
\text { Xpert }^{\circledR} \text { Carba- } \\
\text { R Assay }\end{array}$ & $\begin{array}{l}\text { Sensitivity } \\
\text { (\%) }\end{array}$ & $\begin{array}{l}\text { Specificity } \\
\text { (\%) }\end{array}$ \\
\hline \multirow[t]{7}{*}{$\operatorname{VIM}(n=7)$} & \multirow[t]{2}{*}{ E. coli } & VIM-I & TEM, OXA-I & \multirow[t]{7}{*}{20} & \multirow[t]{7}{*}{20} & \multirow[t]{7}{*}{100} & \multirow[t]{7}{*}{100} \\
\hline & & VIM-I & TEM & & & & \\
\hline & P. stuartii & VIM-I & SHV & & & & \\
\hline & C. farmeri & VIM* & - & & & & \\
\hline & \multirow[t]{2}{*}{ K. pneumoniae } & VIM-I & - & & & & \\
\hline & & VIM-4 & - & & & & \\
\hline & P. mirabilis & VIM-I & - & & & & \\
\hline IMP-I $(n=I)$ & K. pneumoniae & IMP-I & - & 6 & 6 & 100 & 100 \\
\hline \multirow{14}{*}{$\begin{array}{l}\text { Non } \\
\text { carbapenemase } \\
(n=\mid 4)\end{array}$} & \multirow[t]{7}{*}{ E. coli } & - & TEM, SHV, OXA-I & \multirow[t]{14}{*}{21} & \multirow[t]{14}{*}{0} & \multirow[t]{14}{*}{-} & \multirow[t]{14}{*}{100} \\
\hline & & - & $\begin{array}{l}\text { CTX-M group I, TEM-I, } \\
\text { OXA-I }\end{array}$ & & & & \\
\hline & & - & SHV-2a & & & & \\
\hline & & - & SHV-12 & & & & \\
\hline & & - & CTX-M-I5, OXA-I & & & & \\
\hline & & - & CTX-M-2, TEM-I & & & & \\
\hline & & - & CTX-M-I4 & & & & \\
\hline & \multirow[t]{5}{*}{ K. pneumoniae } & - & $\begin{array}{l}\text { CTX-M group I, TEM-I, } \\
\text { OXA-I }\end{array}$ & & & & \\
\hline & & - & CTX-M group I & & & & \\
\hline & & - & CTX-M-I5, TEM-I, SHV-II & & & & \\
\hline & & - & CTX-M group 9 & & & & \\
\hline & & - & CTX-M group I & & & & \\
\hline & \multirow[t]{2}{*}{ E. cloacae } & - & Derepressed AmpC & & & & \\
\hline & & - & $\begin{array}{l}\text { CTX-M group I, TEM-I, } \\
\text { OXA-I }\end{array}$ & & & & \\
\hline
\end{tabular}

Notes: *Variants not determined; -none.

For the prospective study, all tests were negative $(\mathrm{n}=20)$ and were consistent with the phenotypic susceptibility testing. These negative results were predictable due to the still low prevalence of carbapenemase-producing Enterobacteriaceae in France. ${ }^{12}$ Nevertheless, they show that this test is applicable in real-time in clinical laboratories. Thus, a sensitivity and specificity of $100 \%$ were observed, whatever the blood vials used and the duration of the incubation. The main results are summarized in Table 1.

\section{Discussion}

We evaluated the Xpert ${ }^{\circledR}$ Carba-R V2 (Cepheid, Sunnyvale, CA 94089 United States) CPE detection method, directly on positive blood vials, that allows the detection and identification of the main carbapenemase encoding genes in less than one hour whereas most CPE detection techniques require incubation times of several hours to reveal carbapenems hydrolysis. ${ }^{13,14}$ Rapid and accurate identification of CPE types can guide therapies choices and impact patient outcomes. ${ }^{15}$ 
Jaureguy et al reported good performances ${ }^{16}$ of this test on aerobic vials (Becton Dickinson, Franklin Lakes, New Jersey, United States) inoculated with CP isolates, but which did not contain blood. In our study, to approach clinical conditions, we focused on assessing the influence of the patient's blood on the performances of the test. Both the sensitivity and the specificity of the test were of $100 \%$. When increasing the aliquot volume $(400 \mu \mathrm{L})$ and using hemolyzed blood, some results were misleading probably due to the viscosity of samples (possibly dependent on the red blood cells or leukocytes count), indeed, all tests were valid after reducing the aliquot volume to $40 \mu \mathrm{L}$.

Only few assays allow working directly on positive blood culture vials. Among these, the FilmArray ${ }^{\circledR}$ (Biomérieux, Marcy l'Etoile, France) can, up to now, only detect $b l a_{\mathrm{KPC}}$. The Immunochromatographic RESIST-4 O. K.N.V assay (Coris ${ }^{\circledR}$, CorisBioconcept, Belgium) is rapid (15min) but shows a limited sensitivity on class B carbapenemases. $^{7}$ GenMark's ePlex Blood Culture Identification (BCID) panels can detect $b l a_{\mathrm{KPC}}, b l a_{\mathrm{NDM}}$, $b l a_{\mathrm{VIM}}, b l a_{\mathrm{IMP}}$ and $b l a_{\mathrm{OXA}-48}$ genes with results obtained in $1.5 \mathrm{hrs}$, but it is more expensive than the GeneXpert Test.

We identified some limitations in our work. As we privileged the diversity of type of vials (aerobic and anaerobic), the time of incubation and the source of blood, we only tested a limited number of strains and variants of carbapenemase. Furthermore, due to local epidemiology, only 1 IMP-1 isolate was available for this study and all tests conducted in prospective were negative $\mathrm{e}^{12,17}$

\section{Conclusion}

Xpert $^{\circledR}$ Carba-R assay (Cepheid, Sunnyvale, CA 94089 United States) is suitable for the rapid and easy detection of the main carbapenemase genes using the positive blood vials directly. Considering its performances and the rapid analysis, this test is a useful tool not only for therapeutic decision but also to implement hygiene measure precautions. Accordingly, this test respond to most of the "ASSURRED" criteria described by the World Health Organization and defined by affordable, high sensitivity and specificity, user friendly, rapid, easy and long shelf life tests. However, it should be remembered that the GeneXpert test only detects the 5 main types of carbapenemases (bla $a_{\mathrm{KPC}}, b l a_{\mathrm{VIM}}$, $b l a_{\mathrm{IMP}-1}, b l a_{\mathrm{NDM}}$ and $b l a_{\mathrm{OXA}-48}$ or some variants). Therefore, local epidemiology should be taken into account when using this test.

\section{Ethics}

All procedures performed in this study were in accordance with, and with approval from the University Hospital Robert Debré's local ethics committee and with the Helsinki Declaration.

\section{Acknowledgement}

The authors thank Cepheid for kindly providing us part of the test necessary for this study. This study was supported by internal funding.

\section{Disclosure}

The author reports no conflicts of interest in this work. More specifically, they have no association with Cepheid.

\section{References}

1. Seifert H. The clinical importance of microbiological findings in the diagnosis and management of bloodstream infections. Clin Infect Dis Off Publ Infect Dis Soc Am. 2009;48(Suppl 4):S238-S245. doi:10.1086/ 598188

2. Logan LK, Weinstein RA. The epidemiology of carbapenem-resistant Enterobacteriaceae: the impact and evolution of a global menace. J Infect Dis. 2017;215(supp1_1):S28-S36. doi:10.1093/ infdis/jiw282

3. Nordmann P, Poirel L, Dortet L. Rapid detection of carbapenemaseproducing Enterobacteriaceae. Emerg Infect Dis. 2012;18(9):15031507. doi:10.3201/eid1809.120355

4. Birgy A, Bidet P, Genel N, et al. Phenotypic screening of carbapenemases and associated $\beta$-lactamases in carbapenem-resistant Enterobacteriaceae. J Clin Microbiol. 2012;50(4):1295-1302. doi:10.1128/JCM.06131-11

5. Caméléna F, Cointe A, Mathy V, et al. Within-a-day detection and rapid characterization of carbapenemase by use of a new carbapenem inactivation method-based test, CIMplus. $J$ Clin Microbiol. 2018;56:9. doi:10.1128/JCM.00137-18

6. Papagiannitsis CC, Študentová V, Izdebski R, et al. Matrix-assisted laser desorption ionization-time of flight mass spectrometry meropenem hydrolysis assay with $\mathrm{NH} 4 \mathrm{HCO} 3$, a reliable tool for direct detection of carbapenemase activity. J Clin Microbiol. 2015;53 (5):1731-1735. doi:10.1128/JCM.03094-14

7. Cointe A, Bonacorsi S, Truong J, et al. Detection of carbapenemaseproducing enterobacteriaceae in positive blood culture using an immunochromatographic RESIST-4 O.K.N.V. assay. Antimicrob Agents Chemother. 2018;62(12). doi:10.1128/AAC.01828-18

8. Smith M, Diederen B, Scharringa J, Leversteijn-van Hall M, Fluit AC, Cohen Stuart J. Rapid and accurate detection of carbapenemase genes in Enterobacteriaceae with the Cepheid Xpert Carba-R assay. J Med Microbiol. 2016;65(9):951-953. doi:10.1099/jmm.0. 000310

9. O'Connor C, Kiernan MG, Finnegan C, et al. An optimized workflow to reduce time-to-detection of carbapenemase-producing Enterobacteriaceae (CPE) using direct testing from rectal swabs. Bioengineered. 2017;8(3):217-224. doi:10.1080/21655979.2016.122 2335

10. Cortegiani A, Russotto V, Graziano G, et al. Use of Cepheid Xpert Carba- $\mathrm{R}^{\circledR}$ for rapid detection of carbapenemase-producing bacteria in abdominal septic patients admitted to intensive care unit. PLoS One. 2016;11(8):e0160643. doi:10.1371/journal.pone.0160643 
11. Burillo A, Marín M, Cercenado E, et al. Evaluation of the Xpert Carba-R (Cepheid) assay using contrived bronchial specimens from patients with suspicion of ventilator-associated pneumonia for the detection of prevalent carbapenemases. PLoS One. 2016;11(12): e0168473. doi:10.1371/journal.pone.0168473

12. Robert J, Pantel A, Mérens A, Lavigne J-P, Nicolas-Chanoine M$\mathrm{H}$; ONERBA's Carbapenem Resistance Study Group. Incidence rates of carbapenemase-producing Enterobacteriaceae clinical isolates in France: a prospective nationwide study in 2011-12. J Antimicrob Chemother. 2014;69(10):2706-2712. doi:10.1093/jac/ dku208

13. Carvalhaes CG, Cayô R, Visconde MF, et al. Detection of carbapenemase activity directly from blood culture vials using MALDI-TOF MS: a quick answer for the right decision. J Antimicrob Chemother. 2014;69(8):2132-2136. doi:10.1093/jac/dku094
14. Dortet L, Bréchard L, Poirel L, Nordmann P. Rapid detection of carbapenemase-producing Enterobacteriaceae from blood cultures. Clin Microbiol Infect. 2014;20(4):340-344. doi:10.1111/1469-0691.12318

15. Rodríguez-Baño J, Gutiérrez-Gutiérrez B, Machuca I, Pascual A. Treatment of infections caused by extended-spectrum-beta-lactamase-, AmpC-, and carbapenemase-producing Enterobacteriaceae. Clin Microbiol Rev. 2018;31(2). doi:10.1128/CMR.00079-17

16. Jauréguy F, Mansour H, Bigot J, et al. Use of the Xpert CarbaR assay for direct detection of carbapenemase genes from blood cultures and urine samples. J Hosp Infect. 2018;98(3):245-246. doi:10.1016/j.jhin.2017. 09.026

17. Dortet L, Cuzon G, Ponties V, Nordmann P. Trends in carbapenemase-producing Enterobacteriaceae, France, 2012 to 2014. Euro Surveill Bull Eur Sur Mal Transm Eur Commun Dis Bull. 2017;22 (6). doi:10.2807/1560-7917.ES.2017.22.6.30461

\section{Publish your work in this journal}

Infection and Drug Resistance is an international, peer-reviewed openaccess journal that focuses on the optimal treatment of infection (bacterial, fungal and viral) and the development and institution of preventive strategies to minimize the development and spread of resistance. The journal is specifically concerned with the epidemiology of antibiotic resistance and the mechanisms of resistance development and diffusion in both hospitals and the community. The manuscript management system is completely online and includes a very quick and fair peerreview system, which is all easy to use. Visit http://www.dovepress.com/ testimonials.php to read real quotes from published authors. 